\title{
EXCHANGE MARKET PRESSURE INDEX \\ AS A MACROECONOMIC RISK MEASURING INSTRUMENT
}

\author{
Tatiana COLESNICOVA1, PhD in Economics, Associate Professor, \\ National Institute for Economic Research, Republic of Moldova \\ Rodica PERCIUN ${ }^{2}$, Habilitation in Economics, Associate Professor, \\ National Institute for Economic Research, Republic of Moldova \\ Alexandra TVIRCUN ${ }^{3}$, PhD Student, \\ National Institute for Economic Research, Republic of Moldova
}

DOI: https://doi.org/10.36004/nier.es.2020.1-01

JEL Classification: E44, F4, F47, G01

UDC: 330.131.7:336

\section{ABSTRACT}

The financial sector of the Republic of Moldova belongs to the developing ones and is characterized by a higher level of risk and, therefore, a higher likelihood of a systemic crisis. Globalization and development of advanced information technologies not only create great opportunities for rapid economic development, but also pose serious security threats to the economic development of states, especially in a developing economy. In these conditions, the issue of ensuring the financial stability of the state is becoming increasingly relevant. The state of the financial and foreign exchange market represents one of the most important aspects of the financial security of the state. This study has been developed as part of the scientific project 15.817.06.02A "Development of tools for measuring the financial stability of the state". The study analyzes various macrofinancial risk management tools. The purpose of this study was to calculate the pressure index on the foreign exchange market of both the Republic of Moldova and the main partner countries in terms of international trade. The results of related studies conducted by the authors of this work, which revealed that stability indicators in the foreign exchange market are associated with foreign trade risks served as an argument for the authors of the work to calculate the pressure index on the currency market of Romania and the Russian Federation for comparison with the indicators of the Republic of Moldova. Methods used in research include theoretical and comparative approaches, descriptive statistics and econometric models. The results of the research showed that international trade and the foreign exchange market are interdependent. The first can be considered a channel for transmitting the currency crisis, since demand increases with increasing imports, and this leads to increased pressure on the foreign exchange market. Increased exports reduce pressure on the foreign exchange market. But the greatest impact on the foreign exchange market in the Republic of Moldova is made by remittances from abroad, which are directly correlated with the dynamics of labor exports. At the same time, it was concluded that at present, due to macroprudential regulation, there are no linear dependencies in financial markets and, therefore, there are no correlations, but only the interdependence of variables.

Keywords: macroeconomic risk, financial instability, currency crisis, pressure index on the foreign exchange market, countercyclical macroeconomic policies, macroprudential regulation.

Sectorul financiar al Republicii Moldova aparține celor emergente și se caracterizează printr-un nivel de risc mai ridicat și, prin urmare, cu o probabilitate mai mare de apariție a crizei sistemice. Globalizarea şi dezvoltarea tehnologiilor informaţionale avansate generează nu doar mari oportunităţi pentru o dezvoltare economică rapidă, dar creează şi grave ameninţări pentru securitatea, dezvoltarea economică a statelor, mai ales cu o economie emergentă. În aceste condiţii, problema asigurării stabilităţii financiare a statului capătă o amploare tot mai semnificativă. Unul dintre cele mai importante aspecte ale securităţii financiare

\footnotetext{
1 (C) Tatiana COLESNICOVA, $\triangle$ ctania@gmail.com

2 C Rodica PERCIUN, $₫$ rodica21@gmail.com

3 C Alexandra TVIRCUN, alexandra_tvircun@yahoo.com
} 
a unui stat este starea pieței financiar-valutare. Prezentul studiul a fost elaborat în cadrul proiectului 15.817.06.02A „Elaborarea instrumentarului de măsurare a stabilităţii financiare a statului” și analizează diferite instrumente de gestionare a riscurilor macrofinanciare. Scopul prezentei cercetări a constat în calcularea indicelui de presiune al pieței valutare atât a Republicii Moldova, cât și a principalelor țări partenere din punct de vedere al comerțului international. Drept argument al deciziei autorilor de a calcula indicele presiunii valutare a României și a Federației Ruse în coraport cu cel al Republicii Moldova pot servi rezultatele altor studii efectuate de autori, care demonstrează faptul că indicatorii de stabilitate pe piața valutară sunt asociați riscurilor comerciale externe. Metodele utilizate includ abordări teoretice și comparative, statistica descriptivă și modele econometrice. Rezultatele studiului au arătat că comerțl internațional și piața valutară sunt interdependente primul poate fi considerat un canal de transmitere a crizei valutare, deoarece odată cu majorarea importurilor crește cererea, iar aceasta duce la majorarea presiunii asupra pieței valutare. Iar majorarea exporturilor reduce presiunea asupra pieței valutare, dar cel mai mare impact asupra pieței valutare în condițiile Republicii Moldova il au remitențele din străinătate care sunt într-o corelație directă cu dinamica exporturilor de muncă. Totodată, s-a ajuns la concluzia că, în prezent, datorită reglementărilor macroprudențiale, pe piețele financiare nu există dependențe liniare și, în consecință, nu există corelații, doar interdependență variabilă.

Cuvinte-cheie: risc macroeconomic, instabilitate financiară, criză valutară, indicele presiunii asupra pieței valutare, politici macroeconomice contraciclice, reglementare macroprudențială.

Финансовый сектор Республики Молдова относится к развивающимся и характеризуется более высоким уровнем риска и, следовательно, более высокой вероятностью возникновения системного кризиса. Глобализация и развитие передовых информационных технологий не только открывают большие возможности для быстрого экономического развития, но и создают серьезные угрозы безопасности экономическому развитию государств, особенно в условиях развивающейся экономики. В этих условиях вопрос обеспечения финансовой устойчивости государства становится все более актуальным. Одним из важнейших аспектов финансовой безопасности государства является состояние финансово-валютного рынка. Данное исследование было разработано в рамках научного проекта 15.817.06.02A «Разработка инструментов для измерения финансовой устойчивости государства». В исследовании анализируются различные инструменты управления макро-финансовыми рисками. Целью данного исследования явилось вычисление индекса давления на валютный рынок как Республики Молдова, таки основных стран-партнеров с точки зрения международной торговли. Результаты предыдущих исследований авторов выявили, что показатели стабильности на валютном рынке связаны с внешнеторговыми рисками. Это послужило аргументом для решения авторов работы рассчитать индекс давления на валютный рынок Румынии и Российской Федерации для сравнения с показателями Республики Молдова. Используемые методы включают теоретический и сравнительный подходы, описательную статистику и эконометрические модели. Результаты исследования показали, что международная торговля и валютный рынок взаимозависимы. Первый можно считать каналом передачи валютного кризиса, поскольку с ростом импорта увеличивается спрос, а это приводит к усилению давления на валютный рынок. Увеличение экспорта снижает давление на валютный рынок. Но наибольшее влияние на валютный рынок в Республике Молдова оказывают денежные переводы из-за рубежа, которые находятся в прямой корреляции с динамикой экспорта рабочей силы. В то же время, был сделан вывод о том, что в настоящее время из-за макропруденциального регулирования не существует линейных зависимостей на финансовых рынках и, следовательно, нет корреляций, а только взаимозависимость переменных.

Ключевые слова: макроэкономический риск, финансовая нестабильность, валютный кризис, индекс давления на валютный рынок, антициклическая макроэкономическая политика, макропруденциальное регулирование.

\section{INTRODUCTION}

During the transformation stage, the role of national regulation of the financial market of the Republic of Moldova increases with the goal of preventing crisis development. Given that the financial sector of the 
Republic of Moldova belongs to emerging markets, it is characterized by higher levels of risk, and, therefore, a higher likelihood of a systemic crisis. Financial crisis represents an essential element of the systemic economic crisis. The overlapping of two crises makes it difficult to follow the path of sustainable growth and makes structural and institutional reforms a necessity.

Periods of financial instability are accompanied by significant socio-economic losses. Macroeconomic shocks can affect the financial sector through two main channels: first of all, they affect the value and quality of assets that are held in their portfolios by financial institutions; secondly, in terms of general economic instability, the banking sector indicators are deteriorating. An up to date study of systemic risk, the relationship of its indicators with the main macroeconomic indicators, the quantitative assessment of accumulated risk and the development of macroeconomic policies to prevent the buildup of systemic imbalances presents relevance.

The following systemic risks present a potentially greater negative effect for the national economy:

- bankruptcy of certain financial institutions;

- recession in the real sector, negatively affecting the stability of most financial institutions;

- hidden accumulation of imbalances in the financial sector during the cycle (in particular, the rapid growth of unsecured lending, massive investments of revalued assets).

Systemic risks arising in one of the segments extend to other segments of the financial sector and lead to a deterioration in the overall macroeconomic dynamic. Features of the financial market of the Republic of Moldova are associated with the presence of many macroeconomic risks of a systemic crisis (systemic crises are associated with the passage of the country and the world through deep institutional and technological changes, with a change in the technological base, which brings the economy to a whole new level of systemic efficiency), such as:

- weak national currency;

- high level of dollarization of the economy;

- growing external debt;

- budget deficit;

- low GDP growth rate;

- sustainable current account deficit;

- weak banking regulation;

- underdevelopment of the stock market and specialized credit and financial institutions.

A significant channel for the emergence and spread of a crisis in the Republic of Moldova is the foreign economic sector (which comes in the form of an increase in remittances and a growth rate of imports). Crises spread between countries as the key macroeconomic indicators change. The World economic and financial systems are becoming more integrated due to the rapid expansion of international trade in goods, services and financial assets. Along with the intensification of economic integration processes, there is an increase in the level and pace of financial integration. Two systemic crises in the Republic of Moldova (in 1998 and 20082009) were induced by shocks in the balance of payments.

However, the ways in which a crisis spreads can vary. Thus, in accordance with the scientific characteristics, the crisis of 2015 in the Republic of Moldova has the features of both a currency and a banking crisis, which in its turn is defined as a complex crisis. During the crisis period, there was a significant financial and macroeconomic imbalance ("overheating" of the domestic debt market, a breakdown in the economic agents' expense dynamics from the dynamics of their income, etc.).

DEGREE OF SCIENTIFIC APPROACH AND ITS REFLECTIONS IN THE SPECIALIZED LITERATURE

Existing methods and tools for assessing the financial sector are developed by the World Bank and the IMF (Financial Sector Assessment Program - FSAP); Committee attached to the Bank for International Settlements (Basel Committee on Banking Supervision); OECD, International Securities Regulatory Organization (IOSCO), International Association of Insurance Supervisors (IAIS), International Accounting Standards Board (IASB); The Financial Stability Board (Coordinator of the Plenipotentiary Representatives of the National Central Banks, the Ministries of Finance and Financial Market Regulation of the World's Most Developed Countries, and the Major G-20 International Financial Organizations) and others (Perciun 2014; Colesnicova 2015; Perciun, Colesnicova et al. 2018).

It should be noted that the most commonly used crisis prevention instrument is the Early Warning Systems, which allow rapid identification of problems in the economy, based on indicators that emit signals, which facilitates the prompt taking of crisis prevention measures. These early warning systems can be 
defined as a set of processes, models, indicators, which summarize the information and data needed to identify the risks faced by financial institutions, generally the financial system, allowing the forecast of a crisis in a certain period of time in the future (Perciun 2014).

The most updated, developed and applied in practice methods for assessing the risks of the financial sector are the following:

1) the signal, or nonparametric method;

2) probit and logit modeling;

3) building leading indices of crisis.

In contemporary research, the methodology of the "signal" approach has become quite widespread. The "signal" approach using by Graciela Kaminsky, Saul Lizondo and Carmen Reinhartin in 1998 (Kaminsky, Lizondo, Reinhart 1998), is based on an analysis of the behavior of a specific set of macroeconomic and financial indicators, which, in crisis-free periods, refer to the pre-crisis periods and periods of crisis implementation as private. A signal of an approaching crisis, given by one or another private indicator, is considered to be going beyond the range of acceptable (threshold) values. If a private indicator gives out a signal for the predetermined period of time before the crisis (called a "signal window"), then such a signal is referred to as "good". On the contrary, if a private indicator gives a signal, but the crisis does not occur during the signal window, then such a signal is considered "bad" ("noise"). The length of the "signal window" is set expertly.

Thus, based on the analysis of several works, the information on the capacity of indicators to predict the crisis is presented (table 1).

Trends of indicators that predict financial instability

\begin{tabular}{|c|c|c|}
\hline Group of indicators & Indicator & $\begin{array}{l}\text { Trend before } \\
\text { the crisis }\end{array}$ \\
\hline \multirow[t]{4}{*}{ Internal macroeconomic policy } & The growth rate of GDP in constant prices & decrease \\
\hline & The growth rate of outflows in constant prices & decrease \\
\hline & The budget deficit relative to GDP & increase \\
\hline & Unemployment & increase \\
\hline \multirow{9}{*}{$\begin{array}{l}\text { External context (external } \\
\text { economic conditions) }\end{array}$} & Current account balance of payments & decrease \\
\hline & Export & decrease \\
\hline & Import & increase \\
\hline & The balance of payments & decrease \\
\hline & Gold and foreign exchange reserves & decrease \\
\hline & Capital outflow & increase \\
\hline & External debt & increase \\
\hline & Net outflow of capital & increase \\
\hline & Public budget deficit & increase \\
\hline \multirow[t]{5}{*}{ Fundamental indicators } & Money supply & increase \\
\hline & Sufficient reserves & increase \\
\hline & M2 relative to gold and currency reserves & increase \\
\hline & The multiplier & increase \\
\hline & The monetization of economy & increase \\
\hline \multirow{2}{*}{$\begin{array}{l}\text { Financial system health } \\
\text { indicators }\end{array}$} & Internal credit & increase \\
\hline & Deposits & decrease \\
\hline \multirow{6}{*}{$\begin{array}{l}\text { Shocks affecting the financial } \\
\text { sector }\end{array}$} & Inflation & increase \\
\hline & Actual effective exchange rate & increase \\
\hline & Real domestic credit interest rate on the interbank market & increase \\
\hline & Ratio between credit rate and deposit rate (margin) & increase \\
\hline & The spread between the internal credit rate and the LIBOR rate & increase \\
\hline & Trade conditions & decrease \\
\hline $\begin{array}{l}\text { Pressure on the foreign } \\
\text { exchange market }\end{array}$ & The Exchange Market Pressure Index & increase \\
\hline
\end{tabular}

Source: Elaborated by the authors based on their previous researches (Perciun 2014; Colesnicova 2015; Perciun, Colesnicova et al. 2018).

We note that one of the indicators to be monitored is the pressure on the foreign exchange market.

The main signs of a currency crisis are a sharp drop in the exchange rate and the exhaustion of the foreign exchange reserves. In scientific literature, a currency crisis, as a rule, refers to the depreciation of the 
national currency by $25-30 \%$ or more over several months and the same sharp reduction in foreign exchange reserves. Paul Krugman described this type of crisis in the framework of "Balance of Payment Crises and Capital Flight" model (Krugman 1979).

The situation of financial instability of the banking sector is characterized as a full-blown banking crisis if at least one of the following conditions is met:

- the share of bad loans in the total assets of the banking sector exceeds $10 \%$;

- the cost of measures to improve the situation in the industry exceeds $2 \%$ of GDP;

- the result of problems in the banking sector became the nationalization of a significant share of banks;

- there were massive deposit withdrawals from banks (depositor "raids"), emergency measures were applied (freezing deposits, announcing long "bank holidays"), or introduction of mechanisms for state deposit guarantee (Demirguc-Kunt, Detragiache 1998) [2].

Complex crisis - a crisis situation characterized by the simultaneous or sequential manifestation of several types of crises, due to the similarity or interconnectedness of the causes that gave rise to them (World Bank 2012).

The relationships between a systemic risk of the financial sector and a major macroeconomic risk should be taken into account when developing countercyclical macroeconomic policies and macroprudential regulation. Currently, the following risk management tools are applied:

1. macroeconomic instruments are aimed at creating macroeconomic balance, in particular at the achievement of financial stability, overcoming budget deficit, stabilizing inflation, ensuring a positive balance of payments and maintaining a stable national currency rate. Among these tools, we can distinguish the mechanisms of monetary, fiscal policy;

2. institutional instruments are aimed at the formation and regulation of the legal and organizationaleconomic environment, the approval of a single operating procedure for all market entities. Institutional quality plays a significant role in the reduction of the likelihood of both the crisis itself and its continuation. Among these tools we can distinguish the legislative, regulatory, technical regulations;

3. infrastructural support presumes the participation of government agencies in shaping markets for the factors of production (construction of transport infrastructure, transmission mechanisms; financing fundamental science and co-financing applied developments, testing facilities, training, etc.);

4. information tools aimed at creating a single information space, providing economic agents with economic, legal, statistical and other useful information, in its turn resulting in an effective and informed management decision making process. The lack of proper attention to an effective financial monitoring of the Republic of Moldova's economy does not allow timely planning and control of the necessary measures for strategic crisis prevention, as a result of which the state responds to an escalating financial crisis.

An important role in the policy of financial stability should be played by the regulatory policy aimed at sustainable growth achievement. Tinbergian assignment in which, under normal circumstances at least, price stability is assured by interest rate policy while financial stability is assured by macro-financial policies, be they capital requirements or credit restrictions, general or sector-specific. During the crisis, "it is important to ensure an adequate balance between the macroprudential and microprudential regulation of risk control, as well as the development of necessary tools to monitor and evaluate the accumulation of macroprudential risks within the financial system" (Himino 2010). A special role in the achievement of financial stability should be given to the National Bank of Moldova. Problems that arose during the crisis remain relevant for the Republic of Moldova:

-Does the central bank have the necessary tools? Are they outdated due to non-use, or is it necessary to create an administrative or legal basis for the creation of new ones?

- Is the concept of central bank independence adequate and effective enough for new responsibilities? Does it need to expand its legal immunity or make changes in the sphere of legislative supervision in order to fulfill its responsibilities of financial stability?

-Are the loss allocation mechanisms reliable enough to take on the balance sheet risks associated with the policies, such as the recent measures of restoring financial stability?

-Does the central bank require changes in its administrational governance arrangements? (Caruana 2010). 


\section{METHODOLOGY OF SYSTEMIC RISK MEASUREMENT}

The systemic risk quantitative assessment of the financial sector can be carried out by different methods. Table 2 represents the following instruments and methods measuring macroeconomic risk.

Table 2

Approaches of quantifying systemic risk of the financial sector

\begin{tabular}{|c|c|c|c|c|c|}
\hline \multirow{2}{*}{$\begin{array}{l}\text { Target } \\
\text { Approach }\end{array}$} & \multicolumn{3}{|c|}{$\begin{array}{l}\text { Assessment of the financial } \\
\text { system and potential threats }\end{array}$} & \multicolumn{2}{|c|}{ Crisis forecasting } \\
\hline & Stress testing & $\begin{array}{l}\text { Network } \\
\text { methods }\end{array}$ & $\begin{array}{l}\text { Value-at-Risk } \\
\text { based Indicators } \\
\text { (CoVaR, MES, } \\
\text { SRISK) }\end{array}$ & $\begin{array}{l}\text { Indicators of } \\
\text { early } \\
\text { detection }\end{array}$ & $\begin{array}{l}\text { Synthetic } \\
\text { Indexes }\end{array}$ \\
\hline $\begin{array}{l}\text { Approach } \\
\text { essence }\end{array}$ & $\begin{array}{l}\text { Testing financial } \\
\text { institution's } \\
\text { vulnerabilities / the } \\
\text { system integrally to } \\
\text { shock scenarios. }\end{array}$ & $\begin{array}{l}\text { Perception of } \\
\text { the financial } \\
\text { sector as a set } \\
\text { of players } \\
\text { connected by } \\
\text { contracts. }\end{array}$ & $\begin{array}{l}\text { Evaluation of } \\
\text { each } \\
\text { participant's } \\
\text { contribution to } \\
\text { the systemic } \\
\text { risk. }\end{array}$ & $\begin{array}{l}\text { Defining the } \\
\text { onset of a } \\
\text { crisis as an } \\
\text { exceeding } \\
\text { indicator of } \\
\text { the threshold } \\
\text { value. }\end{array}$ & $\begin{array}{l}\text { Identification of } \\
\text { "mode switching } \\
\text { effect" from the } \\
\text { stable } \\
\text { development of } \\
\text { economy to } \\
\text { crisis. }\end{array}$ \\
\hline Benefits & $\begin{array}{l}\text { Identification of } \\
\text { financial institution's } \\
\text { vulnerabilities } \\
\text { Estimated } \\
\text { information for the } \\
\text { risk level } \\
\text { supervision }\end{array}$ & $\begin{array}{l}\text { Tracking the } \\
\text { relationships } \\
\text { between } \\
\text { system } \\
\text { elements }\end{array}$ & $\begin{array}{l}\text { Identification of } \\
\text { institutions the } \\
\text { surveillance and } \\
\text { regulation of } \\
\text { which should be } \\
\text { more } \\
\text { scrupulous }\end{array}$ & $\begin{array}{l}\text { Capacity of } \\
\text { early crisis } \\
\text { tendencies } \\
\text { detection }\end{array}$ & $\begin{array}{l}\text { Aggregation of } \\
\text { high-frequency } \\
\text { market data to } \\
\text { monitor the } \\
\text { situation online }\end{array}$ \\
\hline $\begin{array}{l}\text { Shortcom } \\
\text { ings }\end{array}$ & $\begin{array}{l}\text { Uncertainty of } \\
\text { scenario selection } \\
\text { Errors in the } \\
\text { collection of } \\
\text { statistical } \\
\text { information } \\
\text { Nonlinear } \\
\text { relationships } \\
\text { between the system } \\
\text { elements }\end{array}$ & $\begin{array}{l}\text { High } \\
\text { complexity of } \\
\text { models due to } \\
\text { the numerous } \\
\text { possible } \\
\text { scenarios of } \\
\text { interaction } \\
\text { between the } \\
\text { players. } \\
\text { The necessity } \\
\text { of specifying } \\
\text { the conditions } \\
\text { that simplify } \\
\text { the actual } \\
\text { situation }\end{array}$ & $\begin{array}{l}\text { Existing } \\
\text { indicators giving } \\
\text { conflicting } \\
\text { results. }\end{array}$ & $\begin{array}{l}\text { Sensitivity to } \\
\text { the selection } \\
\text { of the } \\
\text { research } \\
\text { period - } \\
\text { retrospective } \\
\text { functioning }\end{array}$ & $\begin{array}{l}\text { Sensitivity to the } \\
\text { selection of the } \\
\text { research period } \\
\text { - retrospective } \\
\text { functioning }\end{array}$ \\
\hline
\end{tabular}

Source: Elaborated by the authors using (Щепелева 2016).

Stress-test is a more often used tool and allows the assessment of the financial situation of credit institutions and their ability to resist the challenges based on identifying weaknesses in their work. Therefore, stress-tests are a group of methods for financial assessment of an institution in situation of the crisis and the tools for managing economic risks (Perciun 2014; Perciun et al. 2014; Colesnicova 2015; Perciun, Colesnicova et al. 2018).

Calculations of leading crisis indexes

Contemporary literature offers an analytical review of the existing methods for prevention, diagnosis, and intervention to solve crisis situations. In foreign practice, integrated and local "crisis" indicators are being calculated: 
- financial stress indexes (St. Louis Fed FSI; ECB Composite Indicator of Systemic Stress; Kansas City Fed FSI; IMF Advanced Economies FSI; AKRA FSI and others);

- financial condition indexes (Chicago Red FCI; Bloomberg FCI);

- composite leading indicators (SOI TsMAKP);

- pressure index on the foreign exchange market;

- monetary index;

- credit gap and debt burden indicators; etc.

The following conclusions were drawn in this study on the use of the crisis indicators data based on international experience:

1. There is a lack of a clear ideology for building crisis indicators: As a rule, they are randomly "assembled" from various particular indicators, without the presence of internal logic.

2. In modeling of the central monetary institutions' activities, there is a deviation from the existing institutional theory.

3. Difficulties in using certain key indicators (for example, GDP) due to the lack of official monthly data.

4. The multifactorial nature of the process of economic growth, which makes it difficult to choose the correct monetary indicators that should act as real growth drivers.

5. Nonlinearity between some important monetary indicators of parameters for economic growth, which complicates the construction of a simple anticipatory indicator.

6. Identification of future collisions - ignoring minor changes in the monetary climate.

7. Short lags of anticipatory indicators.

8. The absence of a "recognized leader" (Екимова 2018).

The Exchange Market Pressure Index (EMPI)

EMPI is often used as the simplest anticipatory indicator. In 2009, the IMF proposed the use of the IMF financial stress index for the emerging economies, and the EMPI as one of five indicators. This indicator is practically used in different countries.

Firstly, the EMPI is used as a crisis indicator for assessing financial instability, for example, applying the signal approach by using this index by P. Trunin and E. Inozemtsev in 2012 (Trunin, Inozemtsev 2012).

Secondly, the currency pressure index was used to identify the period of financial crisis in the binary choice models, probit and logit models - using by Matthieu Bussiere and Marcel Fratzscher in 2006 (Bussiere, Fratzscher 2006) and also by Graciela Kaminsky and Carmen Reinhart in 2000 (Kaminsky, Reinhart 2000).

Thirdly, the currency pressure index is used to assess the monetary policy within the framework of exchange rate management and to assess the adequacy of the foreign exchange regimes.

Also, the currency pressure index is used to assess the features of regional crises (Mody, Taylor 2007) and integration processes.

The exchange market pressure index, as a rule, is the weighted average of the rate of depreciation of the national currency (usually compared to the US dollar, in nominal or real terms), monthly changes in foreign currency reserves (in percentage terms) and the monthly changes in interest rates.

A financial crisis occurs when pressure in the financial market is abnormally high. The main problem of this methodology is to determine the coefficient value. Various studies suggest using a value ranging from 1.2 to 3 .

$$
\text { Crisis }=\left\{\begin{array}{l}
1, \text { if } \quad E M P_{i t}>\beta \sigma_{E M P}+\mu_{E M P} ; \\
0-\text { in other cases; }
\end{array}\right.
$$

The group of countries significantly affected by the crisis includes countries for which the deviation of the EMP index from its average value adds up to over two standard deviations calculated on the basis of historical values of the EMP index for the analyzed country (Lukianenko et al. 2013). 


\section{DATA SOURCES, METHOD UTILIZED AND EMPI CALCULATIONS}

In the numerous researches there are different methods which used to identify the currency pressure index. Each author proposes his own methodology regarding the calculation of the currency pressure index. The methodology developed by G. Kaminsky and K. Reinhart (Kaminsky, Reinhart 1999) will be applied in the present research. Their approach to identifying the EMP index can be viewed by the following formula (2):

$$
\mathrm{EMPI}_{i, t}=\frac{\Delta e_{i, t}}{e_{i, t}}-\frac{\sigma_{e}}{\sigma_{r}} \times \frac{\Delta r_{i, t}}{r_{i, t}}
$$

where, EMPI $\mathrm{I}_{i, \mathrm{t}}$ - the pressure index of the foreign exchange market for the country i during the period $\mathrm{t}$;

$e_{i, t}$ - the currency exchange rate of the country i in relation to the currency of the base country during the period $\mathrm{t}$;

$\sigma_{\mathrm{e}}$ - the standard exchange rate gap $\left(\Delta \mathrm{e}_{\mathrm{i}, \mathrm{t}} / \mathrm{e}_{\mathrm{i}, \mathrm{t}}\right)$;

$\mathrm{r}_{\mathrm{i}, \mathrm{t}}$ - the international reserves of the country i during the period $\mathrm{t}$;

$\sigma_{\mathrm{r}}-$ represents a standard aberration in foreign international reserves $\left(\Delta \mathrm{r}_{\mathrm{i}, \mathrm{t}} / \mathrm{r}_{\mathrm{i}, \mathrm{t}}\right)$.

Table 3

EMPI calculations, 1995-2018

\begin{tabular}{|l|c|c|}
\hline & EMPI & mean deviation \\
\hline $\mathbf{1 9 9 5}$ & 0.146833 & 0.004492 \\
\hline $\mathbf{1 9 9 6}$ & 0.2427 & 0.004492 \\
\hline $\mathbf{1 9 9 7}$ & -1.79915 & 0.004492 \\
\hline $\mathbf{1 9 9 9}$ & -4.91071 & 0.004492 \\
\hline $\mathbf{2 0 0 0}$ & -1.73474 & 0.004492 \\
\hline $\mathbf{2 0 0 1}$ & -0.47287 & 0.004492 \\
\hline $\mathbf{2 0 0 2}$ & -0.51884 & 0.004492 \\
\hline $\mathbf{2 0 0 3}$ & -0.14992 & 0.004492 \\
\hline $\mathbf{2 0 0 4}$ & 2.354603 & 0.004492 \\
\hline $\mathbf{2 0 0 5}$ & 0.271331 & 0.004492 \\
\hline $\mathbf{2 0 0 6}$ & 0.299702 & 0.004492 \\
\hline $\mathbf{2 0 0 7}$ & 3.507408 & 0.004492 \\
\hline $\mathbf{2 0 0 8}$ & 3.221559 & 0.004492 \\
\hline $\mathbf{2 0 0 9}$ & -1.56308 & 0.004492 \\
\hline $\mathbf{2 0 1 0}$ & -0.23352 & 0.004492 \\
\hline $\mathbf{2 0 1 1}$ & 1.812387 & 0.004492 \\
\hline $\mathbf{2 0 1 2}$ & 2.069182 & 0.004492 \\
\hline $\mathbf{2 0 1 3}$ & 0.872831 & 0.004492 \\
\hline $\mathbf{2 0 1 4}$ & -4.38248 & 0.004492 \\
\hline $\mathbf{2 0 1 5}$ & -6.59638 & 0.004492 \\
\hline $\mathbf{2 0 1 6}$ & 0.917606 & 0.004492 \\
\hline $\mathbf{2 0 1 7}$ & 4.083223 & 0.004492 \\
\hline $\mathbf{2 0 1 8}$ & 2.56232 & 0.004492 \\
\hline Author & 2.00000 & 0.004492 \\
\hline
\end{tabular}

Source: Authors' calculations based on the NBM data.

The growth of the EMPI represents an increase of tension in the foreign exchange market. The crisis is evidenced by values that increase from their average value by more than three standard deviations. A constant increase in the index may indicate a worsening of the economic situation, a decrease of the index may demonstrate the effectiveness of anti-crisis measures, etc.

Based on the theory of currency crises, the instability indicators within the foreign exchange market are associated with the risks of international trade. Given the foreign economic dependence 
of the Republic of Moldova on the export of raw materials and imports of energy resources, it is important to monitor the dynamics of the foreign exchange market in the countries which are the main trading partners of the Republic of Moldova.

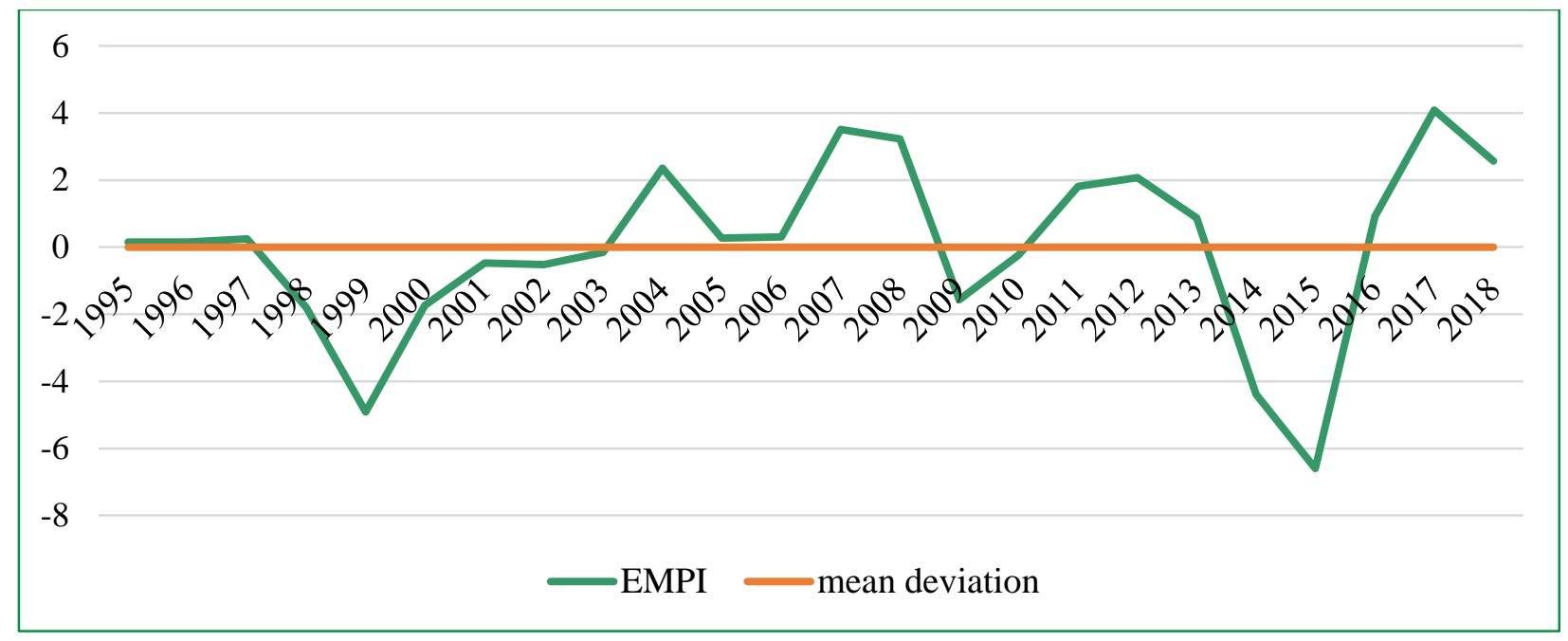

Figure 1. EMPI for the Republic of Moldova, 1995-2018

Source: Elaborated based on authors' calculations.

EMPI increases with the depreciation of the national currency or with the decline of international reserves. The crisis situation is highlighted by values that increase from the average value by more than three standard deviation points. Therefore, in the period 2008-2009, before the crisis, the EMP index exceeded the threshold level 3 times, thus, there was a significant increase of the index two years before the banking crisis in 2014-2015, but the most significant index growth was recorded in 2017, which indicates an increase in the market currency during this period. The consequences of the stressful situations during the crisis periods 98-99, 2009, 2014-2015 began to amortize the national currency against the base currencies and reduce international reserves, especially in 2014 (with an increase of 24.6 p.p.).

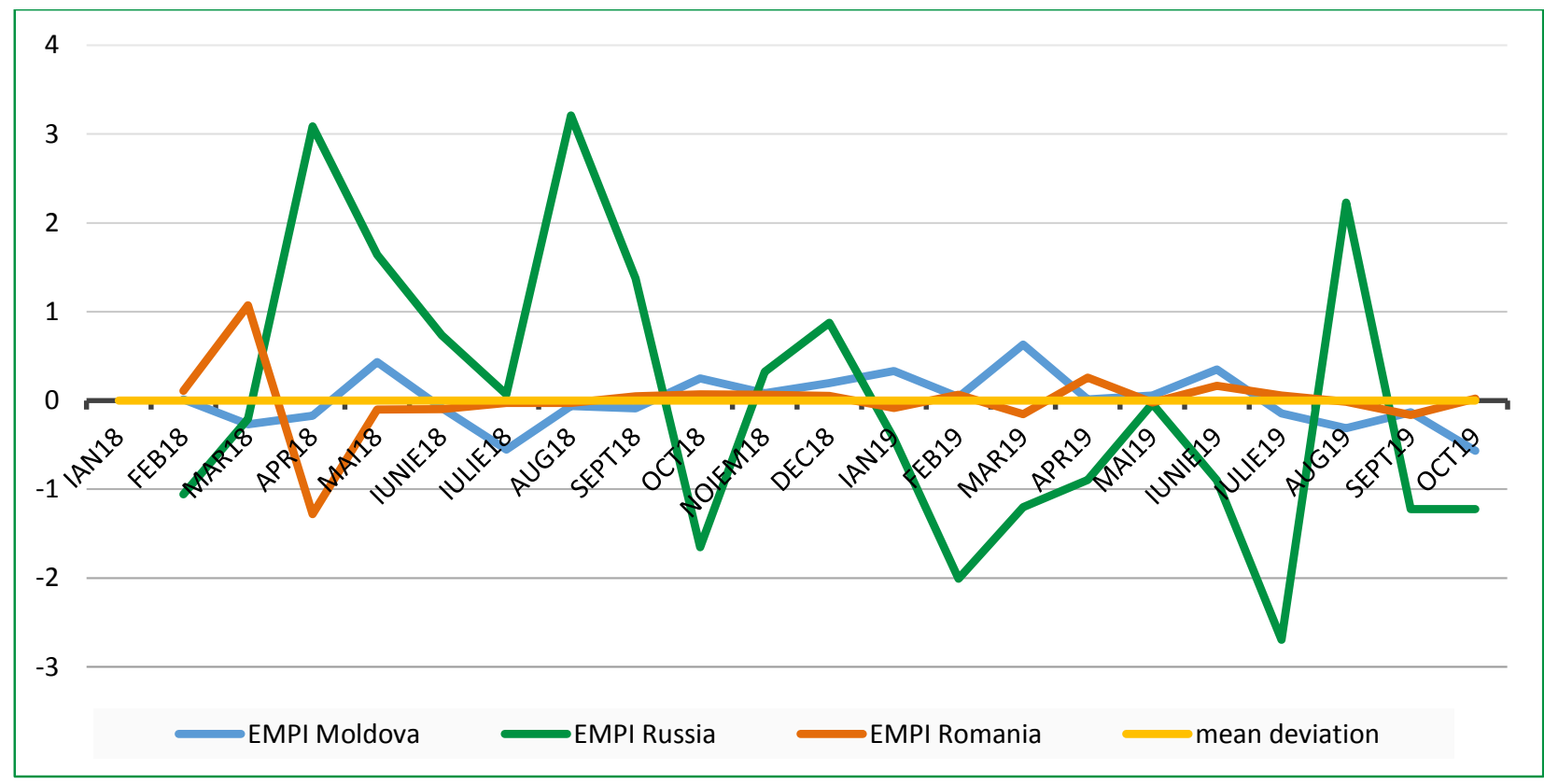

Figure 2. EMPI for the Republic of Moldova, Russian Federation, Romania

Source: Elaborated based on authors' calculations. 
The channels of commercial and financial transactions, the impact of the crisis, may interact with each other, as the availability of commercial credit is related to the volume of trade. Increased imports increase demand and pressure on the foreign exchange market. The increase in exports reduces the pressure on the foreign exchange market, but the biggest impact under the conditions of the Republic of Moldova on the foreign exchange market is due to the dynamics of remittances from abroad. Thus, the highest values of the EMPI indicator for the last two years have been associated with the increase in remittances abroad in spring 2018 and early 2019. However, modern financial markets are so complex and interconnected that there can be no linear dependencies, thus, only variable interdependence.

MAIN CONCLUSIONS

Trade and financial channels for transferring the impact of the crisis can interact with each other, since the availability of trade credit is related to the volume of trade. Import growth increases demand, and pressure on the foreign exchange market increases. Export growth reduces pressure on the foreign exchange market, but the greatest impact in the conditions of the Republic of Moldova on the foreign exchange market is associated with the dynamics of labor exports, or remittances from abroad. Thus, the highest values of EMPI over the past two years were associated with an increase in remittances from abroad in the spring of 2018 and at the beginning of 2019. However, modern financial markets are so complex and interconnected that there can be no linear dependencies, and therefore no correlations, only variable interdependence.

Thus, country-specific sources of vulnerability to external shocks include solvency and liquidity problems, weak domestic balances, and factors associated with an open economy. These factors increase the vulnerability to crises related to the balance of payments, to the capital account, and to the foreign exchange market, and also potentially increase the degree of stress transfer originating from investing countries.

\section{REFERENCES}

1. KRUGMAN, P. A model of balance-of-payments crises. In: Journal of Money, Credit and Banking. 1979, vol. 11, issue 3, pp. 311-325 [citat 19 aprilie 2020]. Disponibil: https://www.gc.cuny.edu/CUNY_GC/media/LISCenter/pkrugman/krugman-BPO-crisis.pdf

2. DEMIRGUC-KUNT, A., DETRAGIACHE, E. The Determinants of Banking Crises in Developing and Developed Countries. International Monetary Fund. In: IMF Staff Papers. 1998, vol. 45, no. 1, pp.81-109 [citat 19 aprilie 2020]. Disponibil: https://www.imf.org/external/Pubs/FT/staffp/1998/03-98/pdf/demirguc.pdf

3. Global Financial Development Report 2013: Rethinking the Role of the State in Finance. World Bank. Washington DC, 2012 [citat 11 aprilie 2020]. Disponibil:

http://documents.worldbank.org/curated/en/853761468326979957/pdf/728030PUB0Publ0 7926B009780821395035.pdf

4. HIMINO, R. Role of regulatory policy in attaining sustainable growth. 2010, march [citat 10 aprilie 2020]. Disponibil: www.dic.go.jp/content/000010396.pdf

5. CARUANA, J. Financial stability: 10 questions and about seven answers. Sydney, 2010, 9 february [citat 18 aprilie 2020]. Disponibil: https://www.bis.org/speeches/sp100209.htm

6. ŜEPELËVA, V. Macroèkonomičeskie aspekty ocenki sistemnogo riska finansovogo sektora: dissertaciâ na soiskanie učënoj stepeni kandidata èkonomičeskih nauk. Moskovskij gosudarstvennyj institut meždunarodnyh otnošenij, Ministerstva inostrannyh del Rossijskoj Federacii. Moskva, 2016 [citat 12 aprilie 2020]. Disponibil: https://mgimo.ru/science/diss/Shcepeleva_Dissertaciya.pdf

7. KAMINSKY, G., LIZONDO, S., REINHART, C. Leading Indicators of Currency Crisis. International Monetary Fund. In: IMF Staff Papers. 1998, vol. 45, no. 1 [citat 21 martie 2020]. Disponibil: https://www.imf.org/external/Pubs/FT/staffp/1998/03-98/pdf/kaminsky.pdf

8. EKIMOVA, N. Makroinstitucional'nyj sintez i ego vozmožnosti. Finansovyj universitet pri Pravitel'stve Rossijskoj Federacii. Sankt-Peterburg, 2018 [citat 11 aprilie 2020]. Disponibil: https://docplayer.ru/123719071-Makroinstitucionalnyy-sintez-i-ego-vozmozhnosti.html

9. TRUNIN, P., INOZEMCEV, È. Monitoring finansovoj stabil'nosti 2011 g. Institut èkonomičeskoj 
politiki im. E.T. Gajdara [citat 11 aprilie 2020]. Disponibil: https://www.iep.ru/ru/publikatcii/category/1336.html

10. BUSSIERE, M., FRATZSCHER, M. Towards a New Early Warning System of Financial Crises. In: Journal of International Money and Finance. 2006, vol. 25, issue 6, pp. 953-973 [citat 19 aprilie 2020]. Disponibil: https://econpapers.repec.org/article/eeejimfin/v_3a25_3ay_3a2006_3ai_3a6 3ap_3a953-973.htm

11. KAMINSKY, G., REINHART, C. On crises, contagion, and confusion. In: Journal of International Economics. 2000, vol. 51, issue 1, pp. 145-168 [citat 18 aprilie 2020]. Disponibil: https://econpapers.repec.org/article/eeeinecon/v_3a51_3ay_3a2000_3ai_3a1_3ap_3a145168.htm

12. MODY, A., TAYLOR, M. Regional vulnerability: The case of East Asia. In: Journal of International Money and Finance. 2007, vol 26, no. 8, pp. 1292-1310 [citat 19 aprilie 2020]. Disponibil: https://www.researchgate.net/publication/222572472_Regional_vulnerability_ The_case_of_East_Asia

13. LUKIANENKO, I., ZHUK, V. et al. Diagnostics of Financial Crisis: analysis, methods, models. 2013. [citat 17 aprilie 2020]. Disponibil: http://ekmair.ukma.edu.ua/bitstream/handle/123456789/2050/Diagnostics\%20Financial\%2 0Crisis.pdf?sequence $=1 \&$ isAllowed $=y$

14. KAMINSKY, G., REINHART, C. The Twin Crises: The Causes of Banking and Balance-of-Payments Problems. In: American Economic Review. 1999, vol. 89, no. 3, pp. 473-500 [citat 15 februarie 2020]. Disponibil: https://www.aeaweb.org/articles?id=10.1257/aer.89.3.473

15. PERČUN, R., PETROVA, T. Finansovaâ bezopasnost' Respubliki Moldova. LAP Lambert Academic Publishing. 2014. 128 s. ISBN 978-3-659-45754-8.

16. PERCIUN, Rodica. Stabilitatea financiară a statului: între teorie şi practică: monografie. Chişinău: Comp. Ed. INCE, 2014. 184 p. ISBN 978-9975-9799-3-1.

17. COLESNICOVA, Tatiana. Piaţa financiară globală: analiză şi perspective $=$ The global financial market: analysis and perspectives. In: Economie şi sociologie = Economy and Eocilology. 2015, nr. 1, pp. 97-104. ISSN 1857-4130 [citat 20 martie 2020]. Disponibil: https://ince.md/uploads/files/1433186322_nr-1-2015-economie-si-sociologie.pdf

18. PERCIUN, Rodica, COLESNICOVA, Tatiana, TIMOFEI, Olga. Analysis of macroeconomic shocks resistance of Moldovan banking sector. In: Knowledge Horizons-Economics. "Dimitrie Cantemir" Christian University, Pro Universitaria. 2018, vol. 10, no. 4, 2018, pp. 61-91. ISSN 2069-0932, E-ISSN 2066-1061 [citat 20 aprilie 2020]. Disponibil: https://www.orizonturi.ucdc.ro/arhiva/KHE\%20nr.\%204\%20\%202018/8.\%20ANALYSIS\%200F\%20MACROECONOMIC\%20\%20SHOCKS.pdf

\section{ARTICLE HISTORY}

Received 08 May 2020

Accepted 25 May 2020 